revival of feuds and forays, two or three the great Sir A., and he of Poland-street hundred years ago, in the highlands and having prescribed for them such medicines islands, where one chieftain burnt the as are suitable to his object, desires them clan of another, as in Macleod's case, or to go to 11, Poland-street, with the preslaughtered them at midnight, as in the scriptions, and in some instances writes valley of Glencoe, was all very well, and the address on the back thereof, and I am in keeping with those times, but the told he personally superintends the dispensattempt to renew hostilities, and embroil ing in Poland-street in the afternoon; but medical journals in professional altercations this I caunot vouch. Now whether suck and abuse, will, I apprehend, meet with a system as this be creditable to a man little encouragement in the present day, who professes to cntertain the greatest and can only draw down just indignation liberality of feeling townrds his medical on the personally interested motives of brethren, I leave the world to judge. It such agitators. If the parties thus incited certainly looks to me very like going down to action have but half the prudence for the professional ladder.

which I give them credit, they will turn a deaf ear to your war.-whoop, oppose reasoning to invective, and pursue their labours in support of liberal reform against the leaden despotism of feudal and monastic institutions. In my next note, I shall calmly examine some of your, or rather your party's, arguments against uniformity of medical education, and the elevation of the "inferior orders" of the profession, to a higher rank and title than they at present possess. Mcan time, let me counsel you as a fricnd, my dear Green, though you may think me your enemy, to let your liver cool, and to lie down on your pillow in peace with your neighbours, so that your sleep may he more refreshing, your tongue cleaner in the morning, and your complexion less tinged with bile and spleen than it is at present. Twelve months hence you will thank me in your heart for this salutary advice.

Yours,

Gracchus.

Jan. 6th, 1834.

SUNDAY ADVICE IN CONDUIT-STREET.

To the Editor of The LANCeT.

Sin,_- Otium cum dignitate" is the motto usually given to men who retire from a life spent in useful labour; but I would suggest the adoption of "otium cum inciignitate" by a certain surgical Baronet. Whether he be worthy of it or not let the following show:-Sir A. Cooper announces that he may be consulted at his house in Conduit-street every Sunday morning, and many persons flock thither to avail themselves of his well-knowr skill in surgical cases, and his supposed skill in medical cases. But what is their astonishment at finding on arrival that the wouthy baronet acts by deputy! A man who has a shop in Poland-strect, Oxfordstreet, sees and prescribes for those who flock to Conduit-st. on Sundays to consult
I am, Sir, your obedient Servant, Dec. 1833 .

Farr Pray。

\section{ROYAL VETERINARY COLLEGE.}

\section{To the Editor of The Lancet.}

Sir,--Although the valuable pages of your reforming Journal have been silent for a long period on veterinary aluuses, yet we have no reason to suppose that you will withhold its powerful advosacy from the oppressed pupils of veterinary science.

Perhaps you were deterred from further exposures of the venality and inefficiency of the St. Parccras sichool by the apparent difficulty of producing any beneficial change in a system so fraught with corruption, - so completely vitiated from its original intention and objects, and so irresponsible in the persons of its oficers.

but, Sir, the lash of well-deserved criticism is seldom applied in vain, and we have to return our thanks to you, the first who boldly took up our cause, for the tardy abolition of more than one malpractice, though trifling indeed when compared with the mass of Augean impurity which still blockades the path of science at this fallacious representation of a British reterinary school, by courtesy called the "Royal College."

I allude in particular to a recent resolution of the governors, according to which a pupil is obliged to pass at least twelve months at the school before he can obtain his diploma, which hard formerly been frequently granted after four or six months, his application having been directed exclusively to the acquisition of Mr. Coleman's peculiar doctrines. This protecting concession was wrung from the ruling powers by the exertions of the liberal press, and chictly through the instrumentaliy of Tre LANCET.

But since your Argus eyc has slumbered, or been directed to other more pressing objects, we have no further act of refor: 
mation to record, but, on the contrary, a series of impositions have been commenced and enforced against the pecuniary interests of the helpless pupils which were never heard of or known before; and I doubt not your medical rearlers, as well as yourself, will be astonished at the amount of exactions under which they labour.

The intentions of the original founders of the Veterinary College will be found in a pamphlet published at its first institution in 1792.- "Rule 5th. Persons qualified according to the rules, will be admitted into the College on paying (to the establishment) twenty guineas, which will constitute them perpetual pupils." And it then proceeds to point out the course of instruction to be pursued, including a course of "Zootomy," another" On the exterior knowledlge of the Horse," a course of "Operations," and one on "Pharmacy and Medical Botany," together with instructions in the "Shoeing Department;"--all comprehended for the sum which is now received by the Professor alone.

Until within these few years past the sum of twenty guineas has been the regu lar admission-fee of a pupil paid to Mr. Coleman, purporting to include every expense excepting the charge for his examination, and for which he was to receive a thorough education in "the principles and practice of the veterinary art." Withont inquiring in this place whether the contract was fulfilled, or what advantages the pupil enjoyed in return for his money, beyond the opportunity of hearing one long course of Mr. Coleman's lectures, the sun of twenty guineas must certainly be allowed as a very sufficient, if not anl exorbitant consideration for all that he might or could learn at this imperfect institution. This was called the initiatory fee, and was the sum which a young man (perhaps of limited means) brought with him from the country in his pocket, and paid down before he could hear more than one specimen of the ingenious sophistry of the learned Professor. But now this initiatory fee, which he had been taught to expect included all things, turns out to be but the beginning of expenses. For of late years, Mr. Assistant Sewell, anxious to become a lecturer, has undertaken to give a short series of discourses, under the head of surgical lectures; not gratuitously nor on Mr. Coleman's account, but for his own peculiar benefit. Now, as Mr. Sewell is an influential person in the College, and moreover has lately been appointed one of the examining committee, each of the pupils is virtually obliged to find five guineas for him, or hazard the hearier penalty of rejection.
In the next place there is attached to the staff of the establishment a gentleman named Morton, who fills the office of clerk to the concern, and compounds the few drugs and simples which are directed by his superiors. Following the bent of their conduct, he is also on the alert to cut and secure his share of the wool from the young flock, and professing to give private lecturcs on pharmacy, he has lately obtained, from nearly all of the pupils, the sum of two guineas cach.

Although precluded (I bclieve by a special rule) from being a veterinary surgeon, this gentleman is still, from his situation and office, a personage of consequence and interest, without whose favour it is difficult to succeed; and, excepting to his pupils, the science of the materia medica is a sealed book at the College.

Again, the official demonstrator, Mr. Sewell, scarcely ever enters the dissectingroom;-but the pupils are mostly willing to give the Professor's Assistant, Mr. Vines, a small acknowledgment of only one guinea a-piece for his laborious attendance and anatomical information.

Furthermore, it would be as likely by "taking thought" for a pupil to "raise his stature one cubit," as that he should pass his examination simply by dine of practical knowledge, study, and dissections; or, in a word, by accomplishment in all that elsewhere constitutes an enlightened veterinarian. He had better divest himself of all this, and imbibe another kind of qualification, viz. a ready $\mathbf{k n o w l e d g e}$ of all Mr. Coleman's fanciful theories, and clsewhere obsolete measures. For this purpose there is an academy at hand, kept by a Mr. Spooner, who perfectly unclerstands this branch of science, and whose charge is from three to five guineas. This cramming process is, in fact, deemed absolntely necessary to the attainment of a diploma.

The present expense of obtaining this piece of paper stands nearly thus :-

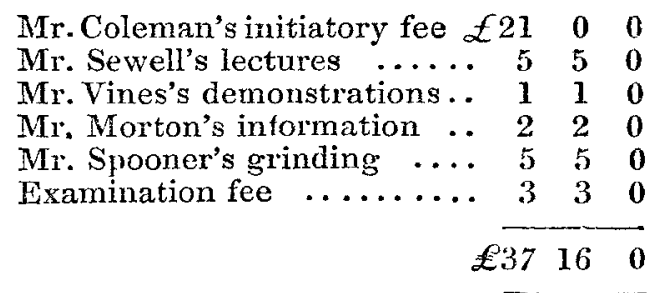

By this it appears that above 70 unsuspecting pupils are obliged to spend nearly 40 guineas each instead of the 20 which they had been taught to expect would bear them harmless, and which goes at once into the pocket of the professor, who 
in return gives a course of lectures and, which can reflect disgrace only on himself. occasional colloquial repasts. There can No such letter as the one addressed "To Je no objection whatever to multiplying the Editor of THe LANCET," inserted in information, whether by lectures or otherwise, but why are not the subordinates paid ont of the ample initiatory fee, instead of being allowed to draw so heavily on the veterinary student, who has in that fee given a full equivalent for all they can teach him? We know not whether these cxactions, all of recent date, are made with or without the knowlerlge of the Governors of the College, - to whom perhaps this statement should with propriety have been addressed, - but those gentlemen have heretofore proved theruselves so careless of the interests of the profession that there is not much reason to hope for a remedy from their intervention. In the meantime, $\mathrm{Mr}$. Editor, I trust you will endeavour to support the oppressed parties, as you have done before, and direct the blame to fall where it is due; and should hou fayour $\mathrm{m}$ by inserting this paper, 1 hum you favon me wheh is certain to afford may hereafter call attention to some other: him confidence in practice, and to secure obnoxious weeds which are flourishing in the rank soil of this abused institution.
I am, Sir,

Yours very respectfully.

Charles Clark.

Veterinary Infirmary, 24, Stamfordstreet, Jan. 8, 1834. the columns of the Mock, has been received at The Lancet Oftice.

A Student. - The Middlesex is, certainly, at the present, the most convenient Hospital for the students of the University, and the clinical remarks of Sir Charres Bur are always instructive. The lec. tures named by our correspondent are judiciously chosen; but those on COMPA. rative Anatomy, delivered by Professor Grant, ought not to be neglected. The practitioner who knows human anatomy only, is not the tenth part of an anatomist. With only an imperfect acquaintance with comparative anatomy, tise student is enabled to acquire and retain a knowledge of for him a conspricuous station in the scientific ranks of his profession.

We are compelled to postpone, until our next Number, the problication of $\mathrm{Dr}$. Smyth s case of fitlse incury om of the atcending portion of the arch of the aonta, and rupture, with effusion of blood into the pesicardinm.

The communications of $M r$. Gravenor, - Mr. Bree (on lodine) - A Kentish Practitioner -A Suffolk Practitioner, - Adans's case, de. LONDON UNIVERSITY AND KING's next wetk.

College. - We may take the number of persons actually attending at the two institutions to be as follows:-

K. C.,ll. Tuiv.

Medical School ....... 90 .. 311

General School ....... $110 \ldots 110$

Junior School........300..260

$$
\text { Total... } \overline{500} \ldots \overline{684}
$$

Mr. Jones must favour us with carefully. drawn outlines of his proposed instuments aim appatidis. The sketrhes betiue ns ate not by any weatis clear enongh for the en wavar.

The next meetings of the Medico-Botami. cal souety and the Heaico-Chirargical socicty take place on the lith inst.

LITERARY INTEILIGENCE.-Dr. Wilson Phnip is preparing a work "On the Effects of Minnte Dosen of Mercnry in Combination with the $\lambda$ ppoprine Theatment of Yarious Diseases in

The number of students attending the, lestoling the Fucions of Hedhu."

medical classes is :-

Anatomy ..........6.60 60.224

Demonstrations ...... 62 .. 213

Chenistry ......... 62 .. 171

Midwifery $\ldots \ldots \ldots \ldots \ldots .49 \quad \ldots \quad 92$

Medical Jurisurudence. . 45 . . 38

-Letter in the Athenceum, Dec. 7, 18:33.

\section{CORRESPONDENTS.}

The person who printel a letter in the last No. of Macrion's Mock, signed "A Guy's Pupil," has taken the pains to write a wilful mis-statement,-a circuustance
Owen Reardon.-A brief notice of the introview was published in Tus Lance' of last weck.

A Country Gentleman.-Certainly, as "surgeon" bui not legally as an "apothecary."

$A$ Poor Country Practitioner.-Before giring it reply, it is necessary that we shonld see ia exact coly of the agl eement butween the parties.

L. M. The " him" was of course a typographical error. Any school-boy must know that the "uid shonld be "his."

Mr. Handey--We receired a copy of the atport, for which we feel oblized, but the care presents nothing new either 11 law or in fact. Surgeons have recoveted for artendance, for centuide, and th. meticul part of the case was hrown ont of count. Nething is now beter unlerstoud than that apothecarics can legally charge for attendance. 